\title{
LATVIJAS ZINĀTNIEKU MŪSDIENU LEDĀJU PĒTİJUMI: NOZĪME, SATURS UN LİDZŠINĒJIE REZULTĀTI
}

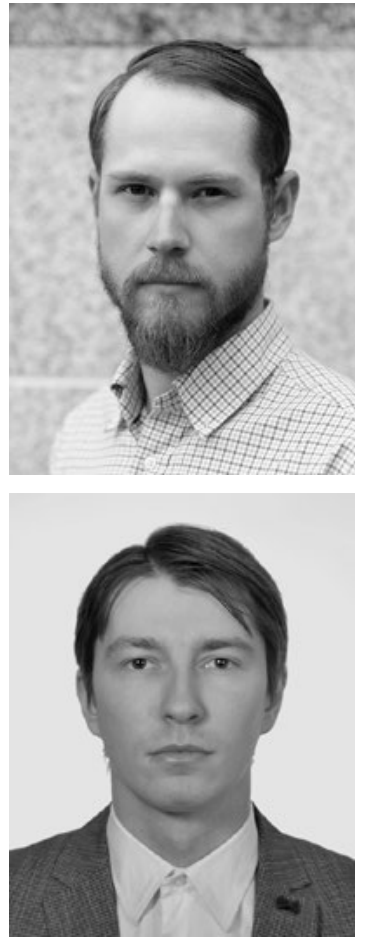

Kristaps Lamsters ir Latvijas Universitātes (LU) Ģeogrāfijas un Zemes zinātṇu fakultātes (G̣ZZF) asociētais profesors, Latvijas Kvartāra pētniecỉbas asociācijas (LATQUA), Starptautiskās Kvartāra pētniecības savienības Latvijas nacionālās komitejas un Starptautiskās Kriosfēras zinātṇu asociācijas Latvijas nacionālās komitejas prezidents, ieguvis geologijas doktora zinātnisko grādu (2015). LU G̣ZZF docē glaciālo geolog̣iju, Latvijas geolog̣iju, kvartārǵeolog̣iju un geomorfolog̣iju. Pētnieciskās intereses: mūsdienu ledāji, seno segledāju dinamika, veidojumi un nogulumi, Latvijas reljefs un geologiskie procesi. Latvijas polāro ekspedīciju organizators un dalībnieks (kopš 2014). Zinātniskā žurnāla Baltica redkolēgijas loceklis. Monogrāfijas Mūsdienu ledāji (2021) autors.

Jānis Karušs ir LU ĢZZF docents, Starptautiskās G̣eodēzijas un geofizikas apvienības Seismolog̣ijas un Zemes uzbūves fizikas asociācijas (IASPEI) Latvijas nacionālās komitejas pārstāvis, ieguvis geeologijas doktora zinātnisko grādu (2015). Docē geofiziku, struktūrǵeolog̣iju, datubāzes un geolog̣isko modelēšanu, radiolokāciju geoloğiskos pētijumos. Pētnieciskās intereses: mūsdienu ledāji, geoofizika, ekonomiskā geolog̣ija, tektonika. Latvijas polāro ekspedīciju organizators un dalībnieks (kopš 2014).

Raksturvārdi: Arktika, Antarktika, ledāji, polārie reǵioni, polārpētniecība, klimata pārmaiņas.

\section{Ievads}

Mūsdienu globālie dati liecina, ka 20. gadsimta beigās, un it īpaši 21. gadsimtā, pasaules ledājiem un ledus vairogiem, kuri kopumā klāj aptuveni $10 \%$ sauszemes virsas, ir vērojams arvien straujāks to masas zudums un negatīva masas bilance ${ }^{1}$. Lielākā daḷa ledus masas pasaulē ir ieslēgta Antarktikas un Grenlandes ledus vairogos, kur ledāji aizṇem attiecīgi 13,9 milj. un 1,7 milj. $\mathrm{km}^{2}$ lielu platību ${ }^{2}$. Būtiska ledāju sarukšana raksturīga Arktikai, kur visspēcīgāk izpaužas pozitīvas atgriezeniskās saites mehānisms, veicinot arvien straujāku ledus kušanu. Lielāko daļu Arktikas ledāju masas zuduma nodrošina Grenlandes ledus vairogs, kura kopējā ledus masas bilance laika posmā no1997. lìdz 2002. gadam bija $-44 \pm 35$ miljardi tonnu, savukārt no 2007. līdz 2012. gadam jau $-75 \pm 28$ miljardi tonnu ${ }^{3}$. Kopumā no 1992. līdz 2018. gadam Grenlandes ledus vairogs zaudēja $3902 \pm 342$ miljardus tonnu ledus masas, paaugstinot globālo jūras līmeni

\footnotetext{
1 WGMS 2020.

2 Benn, Evans 2010.
}

3 The IMBIE Team 2020. 
Tabula. Mūsdienu ledāju zinātnisko ekspedīciju norises laiks un dalībnieki

\begin{tabular}{lll}
\hline Gads & \multicolumn{1}{c}{ Vieta } & \multicolumn{1}{c}{ Dalībnieki } \\
\hline 2014 & Islande & Kristaps Lamsters, Jānis Karušs, Dāvids Bērziņš \\
\hline 2015 & Islande & Kristaps Lamsters, Jānis Karušs, Dāvids Bērziņš, Aleksandrs Vlads \\
\hline 2016 & Grenlande & Kristaps Lamsters, Jānis Karušs, Māris Krievāns, Agnis Rečs, Reinis Pāvils \\
\hline 2017 & Islande & Kristaps Lamsters, Jānis Karušs, Māris Krievāns, Agnis Rečs \\
\hline 2018 & Antarktika & Kristaps Lamsters, Jānis Karušs, Māris Krievāns \\
\hline 2018 & Islande & Kristaps Lamsters, Jānis Karušs, Māris Krievāns, Jurijs Ješkins \\
\hline 2019 & Svalbāra & Kristaps Lamsters, Jānis Karušs, Pēteris Džeriņš, Ingus Pērkons \\
\hline 2021 & Svalbāra & Kristaps Lamsters, Jānis Karušs, Pēteris Džeriņ̌̌s, Jurijs Ješkins \\
\hline
\end{tabular}

par 10,8 $\pm 0,9 \mathrm{~mm}^{4}$. Lìdzīgā laika posmā no 1992. līdz 2017. gadam Antarktikas ledus vairogi zaudēja $2720 \pm 1390$ miljardu tonnu ledus, paaugstinot globālo jūras lìmeni par $7,6 \pm 3,9$ milimetriem ${ }^{5}$.

Lai noskaidrotu ledāju sarukšanas mehānismus un izstrādātu precīzas prognozes par to dinamiku nākotnē, zinātniekiem nepieciešams detalizēti izprast mūsdienu ledāju darbību un attīstības virzību, kā arī litosfēras, atmosfēras, hidrosfēras un kriosfēras procesu mijiedarbību. Ieguldījumu mūsdienu ledāju izpētē devuši arī LU zinātnieki, kuri no 2014. gada îsteno zinātniskās ekspedīcijas un veic pētījumus ledājos Arktikā un Antarktikā. Pētījumu galvenais mērḳis ir attīstīt polāro pētījumu jomu Latvijā, savukārt specifiskie pētniecības mērḳi ir bijuši atšķirīgi katrā ekspedīcijā, un tie ietver ledāju biezuma, iekšejjās struktūras, termiskās un noteces sistēmas, virsmas izmainu, gultnes topogrāfijas, kā arī ledāju un pieledāja teritorijas vides, ekoloğijas un piesārṇojuma pētijjumus.

\section{Zinātnisko ekspedīciju norises vietas un dalïbnieki}

Latvijā polārpētniecība līdz šim galvenokārt ir bijusi saistīta ar diviem izciliem polārpētniekiem - Ivaru Sīli, kurš savu mūžu veltījis galvenokārt Grenlandes un tās dzivās

\footnotetext{
4 The IMBIE Team 2020.

5 Shepherd et al. 2018.
}

dabas izzināšanai, un Leonīdu Slaucītāju (1899-1971), kurš 20. gadsimta 50. gados organizējis geofizikālos pētījumus trijās Argentīnas antarktiskajās ekspedīcijās ${ }^{6}$.

Kopš 2014. gada Latvijā polārpētniecības virzienu attīsta galvenokārt LU G̣ZZF geologi, īstenojot zinātniskās ekspedīcijas uz Islandes, Grenlandes, Svalbāras arhipelāga (Špicbergenas) un Antarktikas ledājiem (tabula). Pirmos pētijumus veica LU G̦ZZF G̦eoloğijas nodaḷas doktorantūras studenti $\mathrm{K}$. Lamsters un J. Karušs, kā arī mağistrantūras students D. Bērziņš, ierakstot pirmos mērïjumus ar georadaru Hofsjokula ledus kupola izvadledājos Islandes centrālajā daḷā. Viens no galvenajiem šo pētījumu uzdevumiem bija izvērtēt georadara lietojamības iespējas ledāju pētījumos. Turpmākās ekspedīcijas līdz 2017. gadam norisinās Islandē un Rasela izvadledāja apkārtnē dienvidrietumu Grenlandē.

Savukārt 2018. gadā pirmo reizi tika organizēta latviešu zinātnieku ekspedīcija uz Antarktiku. Tā norisinājās Kristapa Lamstera pēcdoktorantūras projekta (ERAF) ietvaros ar LU fonda (mecenāts SIA Mikrotìkls), SIA Cel̦u būvniecības sabiedrības "Igate" finansiālu atbalstu. Ekspedīcijā piedalījās Jānis Karušs, Kristaps Lamsters un Māris Krievāns. Tā tika îstenota sadarbībā ar Ukrainas

\footnotetext{
6 Pieejams: https://web.archive.org/ web/20160305090328/http://foto.lu.lv/ avize/19981999/ua13/leo.htm (13.05.2021.).
} 
Nacionālo Antarktikas pētījumu centru, kas pārvalda akadēmiķa Vernadska polārstaciju Vilhelma arhipelāga Argentīnas salu grupas Galindesa salā.

2019. gadā zinātniskā ekspedīcija devās uz Špicbergenas salas rietumdaļas Kafieiras reǵionu Svalbāras arhipelāgā, kur atrodas Nikolaja Kopernika Universitātes Toruṇā polārstacija. Ekspedīcijā piedalijās geologi Kristaps Lamsters, Jānis Karušs un Pēteris Džeriņš, kā arī Pārtikas drošības, dzīvnieku veselības un vides zinātniskā institūta $B I O R$ pētnieks Ingus Pērkons, kurš ievāca paraugus noturīgo organisko piesārṇotāju izplatības analīzēm Svalbāras arhipelāgā. Tādējādi tika paplašināti polāro pētijumu virzieni Latvijā un aktualizētas arī problēmas, kas saistītas ar globālajām vides izmaiñām.

Nākamā ekspedīcija Covid-19 pandēmijas dēḷ norisinājās tikai 2021. gadā, kad zinātnieki atgriezās Svalbāras arhipelāgā, lai izpētītu Valdemarbrēena ledāja virsmas un termiskās struktūras izmaiņas, kā arī veiktu jaunus mērījumus uz Irenabrēena ledāja. Šie pētījumi veikti Latvijas Zinātnes padomes projektā $\mathrm{Ka}$ fijoras reǵiona (Ziemel̦rietumu Svalbāra) ledāju termālā struktūra, noteces sistēmas uzbūve un virsmas izmainas (lig. Nr. lzp-2020/2-0279). Pandēmijas dēl uz 2022. gadu pārcelta plānotā ekspedīcija uz Kānākas ledus kupolu ZR Grenlandē, kurai finansējums piešķirts INTERACT (https://eu-interact.org/) projektā.

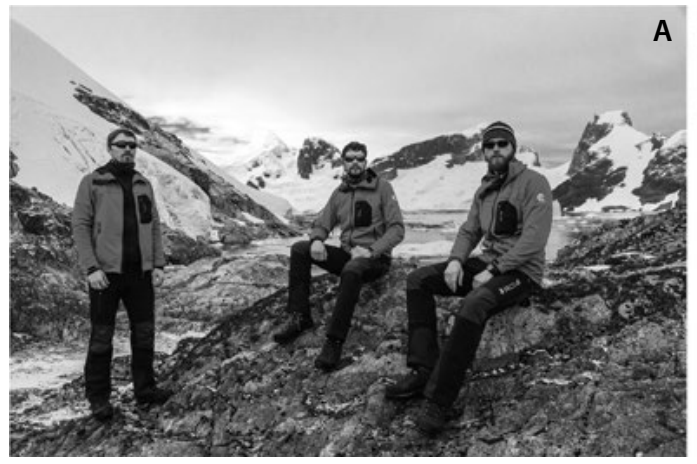

\section{Ledāju pētījumu metodika}

Pirmajās ekspedīcijās uz Islandi pētījumi tika veikti, izmantojot tikai Latvijā ražotu georadaru Zond-12e ar zemas frekvences antenu. Iekārta tika lietota, lai mērītu ledus biezumu, kā arī izpētìtu iekšledāja struktūru. Pētijumos uzmanība pievērsta galvenokārt ledāja gultnē sastopamajām reljefa formām, kā arī iekšledāja ūdeṇu noteces sistēmai un ledāju termiskajai struktūrai. Ekspedīcijā uz Grenlandi pirmo reizi tika izmantots bezpilota lidaparāts $(D J I$ Phantom 3 Advanced) aerofotogrāfiju ieguvei. N̦emot vērā to, ka no bezpilota lidaparāta datiem izdevās izveidot augstas izšķirtspējas ledus virsmas augstuma (3D) modeli, tie ir tikuši lietoti visās turpmākajās ekspedīcijās. Tādējādi ledāju pētijumos, izmantojot georadaru (1. attēls) un bezpilota lidaparātus, iegūti dati, kas ḷauj izveidot pētīto ledāju augstas precizitātes gultnes un virsmas model̦us un pilnvērtīgi raksturot ledāju geometriju un to zemledāja virsmas topogrāfiju. Papildus glaciologiskiem pètījumiem kopš ekspedīcijas uz Grenlandi uzmanība tikusi pievērsta arī pieledāja teritorijām. Ekspedīciju laikā ievākti pieledāja teritorijās sastopamo nogulumu, augšnu, floras, faunas atlieku paraugi, kā arī paraugi no ledus virsas. Tie izmantoti, lai novērtētu dažādu sedimentācijas procesu ietekmi uz grunts graudu morfologiju, augsnes procesu attīstíbu ledājam pieguḷošajā teritorijā, mikroorganismu daudzveidỉbu, kā arī piesārṇojumu.

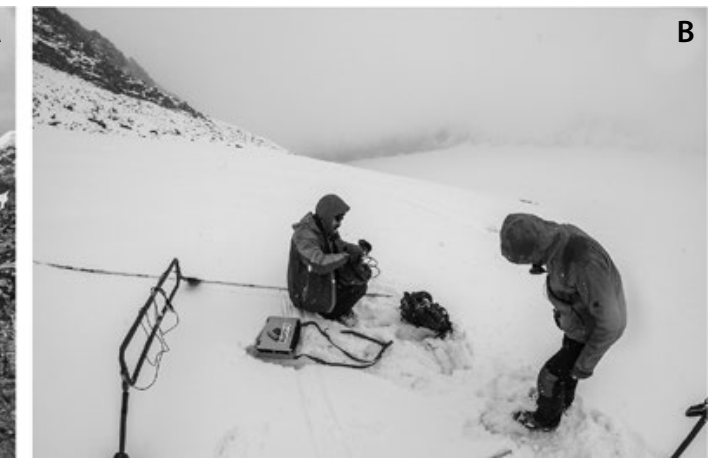

1. attēls. Latvijas polārpētnieki Antarktīdā (A). No kreisās: Jānis Karušs, Māris Krievāns, Kristaps Lamsters. Mērijumi ar georadaru uz Valdemarbrēena ledāja Svalbārā (B)

Foto: no autoru personiskā arhīva 


\section{Ledāju pētījumu rezultāti}

LU GTZZF zinātnisko ekspedīciju uz mūsdienu ledājiem rezultāti šobrīd publicēti 12 zinātniskos rakstos, kas indeksēti Scopus datubāzē (no tiem 8 indeksēti arī Web of Science datubāzē), vairākos citos rakstu krājumos sadarbībā gan ar Latvijas, gan ārzemju vairāku dažāda profila zinātnisko institūciju pētniekiem$^{7}$, kā arī monogrāfijā Mūsdienu ledāji ${ }^{8}$.

Islandes ekspedīcijās 2014. un 2015. gadā veikti radiolokācijas mērījumi uz Mūlajokula izvadledāja. Šis ledājs ir unikāls pasaules mērogā, jo pie tā sastopams mūsdienu lielākais zemledāja veidoto plūdlīnijas reljefa formu (drumlinu) lauks pasaulēê . LU geologu pètījumos drumlini atklāti arī zem Mūlajokula ledāja un noteikta to iespējamā zemledāja izplatības robeža ${ }^{10}$. Pētījumā pirmo reizi pasaulē tika identificēti drumlini zem mūsdienu ledājiem ziemel̦u puslodē, kā arī raksturoti to morfologiskie parametri un saistība ar plaisu sistēmām ledājā.

2016. gada Grenlandes ekspedīcijas pētijumu rezultātā izveidoti Grenlandes ledus vairoga Rasela izvadledāja ziemel̦u daḷas virsmas un gultnes reljefa model̦i, kā arī identificèts iespējamais iekšledāja tunelis, pa kuru noplūst ledājūdeñi no ledāja sprostezera katastrofālu plūdu laikā ${ }^{11}$. Sadarbībā ar LU G̣ZZF paleoekologijas jomas speciālistu Normundu Stivriņu un Nikolaja Kopernika Universitātes Toruṇā sedimentolog̣i Editu Kaliņsku raksturots ledāja virsmā sastopamo izkusuma (kriokonīta) bedrīšu minerālais un organiskais sastāvs, konstatējot mikroorganismu (zaļalı̆gu un ciānbaktēriju) daudzveidības un sfērisko izdedžu dal̦iṇu koncentrācijas mainību ledāja virsmāā', kā arī analizējot kvarca graudu mikrotekstūras un to veidojošos aǵentus ${ }^{13}$.

\footnotetext{
7 Lamsters et al., 2016; Kalińska-Nartiša et al., 2017a, b; Chernov et al. 2018a, b; Stivrins et al. 2018; Karušs et al. 2019; Lamsters et al. 2019a, b; Lamsters et al. 2020a, b, c, d; Kalińska et al. 2021.

8 Lamsters 2021.

9 Johnson et al. 2010.

10 Lamsters et al. 2016.

11 Lamsters et al. 2020a.

12 Stivrins et al. 2018.

13 Kalińska-Nartiša et al. 2017a, b.
}

2017. gada Islandes ledāju pētījumu rezultāti iegūti sadarbībā ar E. Kaliņsku, un zinātniskajā publikācijā aktualizēts jautājums, vai glaciālā vide rada glaciālas izcelsmes kvarca graudus ${ }^{14}$. Pētījumi veikti arī sadarbībā ar vairāku atšḳirīgu jomu zinātniekiem no LU G̦ZZF, LU Mikrobiologijas un biotehnologijas institūta un Latvijas Biomedicīnas pētijumu un studiju centra. Pētījumā raksturota mikroorganismu taksonomiskā un funkcionālā daudzveidība dažāda vecuma pieledāja ezeru nogulumos ${ }^{15}$, atklājot jaunas sakarības par mikroorganismu ekologiju.

2018. gadā īstenotas divas zinātniskās ekspedīcijas - uz Islandi un Antarktiku. Islandē izpētìtas tās lielākā ledus kupola Vatnajokula izvadledāja Eijabakajokula virsmas struktūras un augstuma izmainas, termiskie apstākḷi, biezums un zemledāja topogrāfija. Identificēts līdz $45 \mathrm{~m}$ dziḷš, iegarens erozijas padziḷinājums, kas veidojies daudzkārtīgu ledāja uzplūdu laikân ${ }^{16}$. Pētījumā arī pievērsta uzmanība georadara datu interpretācijas problemātikai un radargrammās novērojamās vāju atstarojumu zonas izcelsmei saistībā nevis ar auksta ledus klātbūtni, bet ar pjezometrisko virsmu ledājā.

Antarktikas ekspedīcijas rezultāti pirmo reizi l̦āva raksturot Argentīnas salu ledus kupolu izplatību, biezumu, uzbūvi, virsmas un gultnes reljefu ${ }^{17}$. Pēc ekspedīcijas datiem izveidotas gan salu ortofotokartes un virsmas digitālie model̦i (2. attēls), kas brīvi pieejami jebkuriem zinātniekiem ${ }^{18}$, gan salu ledāju biezuma un zemledāja reljefa modeḷi. Šie jaunie dati sniedz līdz šim nezināmu augstas detalizācijas informāciju par ledājiem, kuri uzskatāmi par klimata pārmainu indikatoriem Antarktīdas pussalas apkārtnē. Daļa ekspedīcijā iegūto paraugu joprojām tiek analizēti, savukārt Latvijas Biomedicīnas pētījumu un studiju centra pētnieks N̦ikita Zrelovs ir veicis Antarktīdas augšņu analīzes un atklājis līdz šim nezināmus baktēriju vīrusus (bakteriofāgus). Sadarbībā ar antarktiskās ekspedīijas

\footnotetext{
14 Kalińska et al. 2021.

15 Lamsters et al. 2020d.

16 Lamsters et al., 2020c.

17 Chernov et al. 2018a, b; Karušs et al. 2019; Lamsters et al. 2019a, b, 2020 b.

18 Lamsters et al. 2020b.
} 

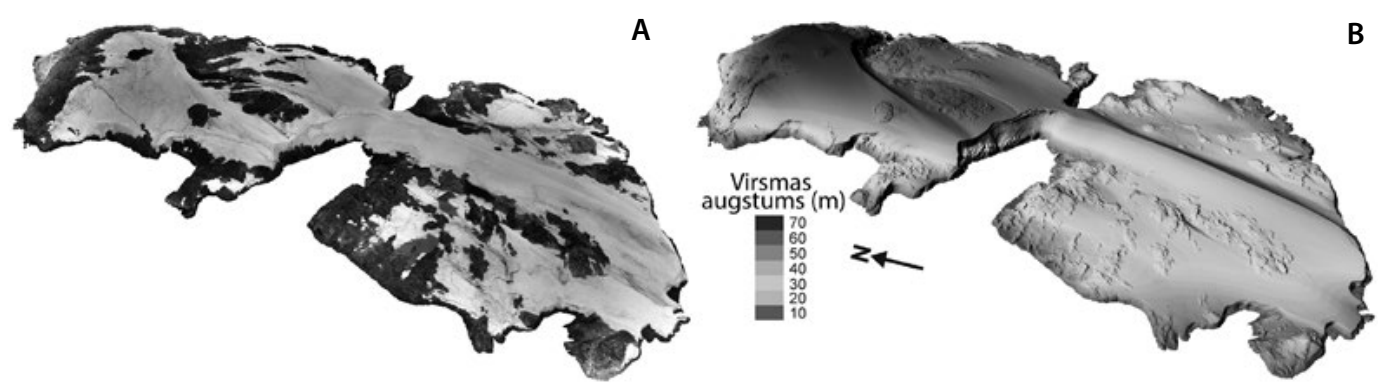

2. attēls. A. Urugvajas salas Antarktikā ortofoto. B. Salas virsmas modelis

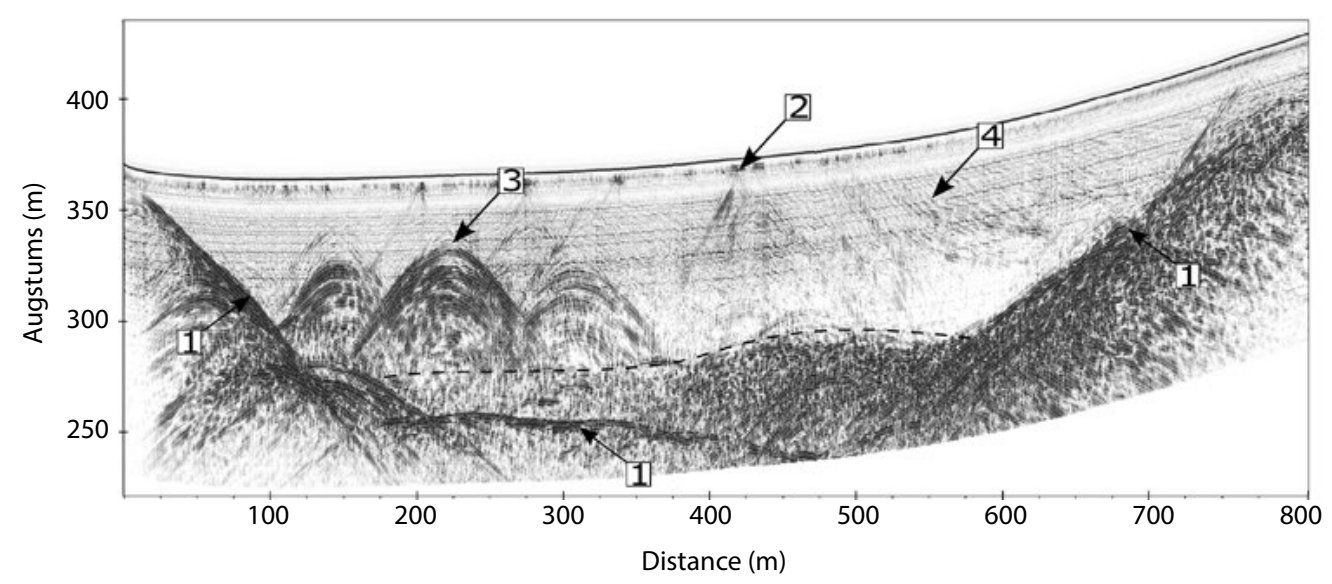

3. attēls. Iekšējās uzbūves piemērs no Valdemarbrēena ledāja Svalbārā. Ar cipariem atzīmēti georadara signāla atstarojumi no (1) ledāja gultnes, (2) plaisas, (3) iekšledāja tunệa un (4) primārā ledus slāņojuma

komandu jaunatklātajam bakteriofāgam, to oficiāli reğistrējot, tika pieškirirts nosaukums Sporosarcina phage Lietuvens.

2019. gadā septītajā zinātniskajā ekspedīcijā LU geologi izpēta Valdemarbrēena ledāja termisko struktūru un iekšledāja noteces sistēmas veidošanos Svalbārā (3. attēls). Pētījumos atklāta ledāja politermālā struktūra, kuru veido daḷeji relikts silta ledus slānis ledāja akumulācijas zonas pamatnē, virs kura visā pārējā ledājā izplatīts auksts ledus. Nozīmīgākais atklājums saistās ar iekšledāja tuneḷu izvietojuma rekonstrukciju un to potenciālā veidošanās mehānisma noskaidrošanu saistībā ar hidroplaisāšanu ledājā. Ekspedīcijas rezultāti pieņemti publicēšanai Starptautiskās Glacioloǵijas savienības žurnālā Journal of Glaciology.
2021. gada ekspedīcijas uz Svalbāru zinātniskie dati vēl ir apstrādes sākumposmā, bet paredzams, ka tie sniegs jaunas zināšanas par vairāku Arktikas kalnu ieleju ledāju virsmas un termiskās struktūras izmaiṇām, kas mūsdienās norisinās sevišḳi strauji.

\section{Nobeigums}

Mūsdienu klimata un aizvien straujāku apkārtējās vides pārmaiṇu kontekstā palielinās detalizētu mūsdienu ledāju pētījumu nepieciešamība un nozīmība. Kopš 2014. gada ledāju pētījumus Arktikā un Antarktikā īsteno arī LU ĢZZF zinātnieki sadarbībā ar vairākām zinātniskajām institūcijām Latvijā un ārzemēs. Pētījumos izstrādāta metodika, 
lai veiktu augstas precizitātes geofizikālos mērỉjumus ledājos un iegūtu aerofotogrāfijas no bezpilota gaisa kuǵiem. No iegūtajiem datiem un attēliem tiek izveidoti ledāju virsmas, ledus biezuma un zemledāja reljefa augstuma modeḷi. Pētījumu rezultāti l̦auj identificēt aukstus, siltus un politermālus ledājus, izvērtēt to biezumu, iekšéjo struktūru, noteces sistēmu, termikas, virsmas augstuma un malas stāvokḷa atškirības un izmainas, kas ir vieni no būtiskākajiem faktoriem ledāju dinamikas izpratnē. Mūsdienu ledāju pētījumi zinātniekiem ḷauj labāk izprast arī seno ledāju darbỉbu Latvijas teritorijā.

Lai turpmāk attīstìtu polāro pētījumu jomu Latvijā, nepieciešams mērḳtiecīgs valsts atbalsts ilglaicīgai pētījumu programmai. Lai aizstāvētu savas intereses un iekḷautos globāli nozīmīgu jautājumu risināšanā un pētniecībā, Latvijai ieteicams pievienoties Antarktikas Lìguma sistēmai un Arktikas padomei novērotājvalsts statusā.

\section{VĒRES}

Benn, D. I.; Evans, D. J. A. (2010) Glaciers and glaciation. 2nd. ed. London : Hodder Education.

Chernov, A.; Karušs, J.; Lamsters, K.; Krievāns, M.; Otruba, Y. (2018a) First results of glacier monitoring on Woozle Hill (Galindez Island, the Argentine Islands, Antarctica) for the period April 2017-August 2018. 12th International Conference on Monitoring of Geological Processes and Ecological Condition of the Environment.

Chernov, A.; Lamsters, K.; Karušs, J.; Krievāns, M.; Otruba, Yu. (2018b) A Brief Review of Ground Penetrating Radar Investigation Results of Ice Caps on Galindez, Winter and Skua Islands (Wilhelm Archipelago, Antarctica) for the period April 2017-January 2019. Ukrainian Antarctic Journal, 1, 17, 40-47.

ISPRS Annals of the Photogrammetry, Remote Sensing and Spatial Information Sciences, 2, 757-763.

Johnson, M. D.; Schomacker, A.; Benediktsson, Í. Ö.; Geiger, A. J.; Ferguson, A.; Ingólfsson, Ó. (2010) Active drumlin field revealed at the margin of Múlajökull, Iceland: a surge-type glacier. Geology, 38, 10, 943-946.

Kalińska-Nartiša, E.; Lamsters, K.; Karušs, J.; Krievāns, M.; Rečs, A.; Meija, R. (2017a) Fine-grained quartz from cryoconite holes of the Russell Glacier, southwest Greenland - a scanning electron microscopy study. Baltica, 30, 2, 63-73.

Kalińska-Nartiša, E.; Lamsters, K.; Karušs, J.; Krievāns, M.; Rečs, A.; Meija, R. (2017b) Quartz grain features in modern glacial and proglacial environments: A microscopicstudy from the Russell Glacier, southwest Greenland. Polish Polar Research, 38, 3, 265-289.

Kalińska, E.; Lamsters, K.; Karušs, J.; Krievāns, M.; Rečs, A; Ješkins, J. (2021) Does glacial environment produce glacial mineral grains? Pro-and supra-glacial Icelandic sediments in microtextural study. Quaternary International. doi.org/10.1016/j.quaint.2021.03.029.

Karušs, J.; Lamsters, K.; Chernov, A.; Krievāns, M.; Ješkins, J. (2019) Subglacialtopography and thickness of ice caps on the Argentine Islands. Antarctic Science, 31, 6, 332-334.

Lamsters, K.; Karušs, J.; Rečs, A.; Bērziņš, D. (2016) Detailed subglacial topography and drumlins at the marginal zone of Múlajökull outlet glacier, central Iceland: evidence from low frequency GPR data. Polar Science, 10, 4, 470-475.

Lamsters, K.; Krievāns, M.; Karušs, J. (2019a) Argentīnas salu (Vilhelma arhipelāgs, Antarktika) ledus kupolu geofizikālie pētījumi. İjabs, I. (red.) Perpetuum mobile 2019: Latvijas Universitātes fonda mecenātu atbalstīto pētnieku zinātniskais rakstu kräjums. Rīga : LU Akadēmiskais apgāds.

Lamsters, K.; Karušs, J.; Krievāns, M.; Ješkins, J. (2019b) Application of unmanned aerial vehicles for glacier research in the Arctic and Antarctica. Environment. Technology. Resources: Proceedings of the 12th International Scientific and Practical Conference, I. Rezekne : Rezekne Academy of Technologies 1, 131-135.

Lamsters, K.; Karušs, J.; Krievāns, M.; Ješkins, J. (2020b) High-resolution orthophoto map and digital surface models of the largest Argentine Islands (the Antarctic) from unmanned aerial vehicle photogrammetry. Journal of Maps, 16, 2, 335-347.

Lamsters, K.; Karušs, J.; Krievāns, M.; Ješkins, J. (2020c) The thermal structure, subglacial topography and surface structures of the NE outlet of Eyjabakkajökull, east Iceland. Polar Science, 26, 100566, https:// www.sciencedirect.com/science/article/abs/pii/S187396522030075X?via\%3Dihub 
Lamsters, K.; Ustinova, M.; Birzniece, L.; Silamiķelis, I.; Gaidelene, J.; Karušs, J.; Krievāns, M.; Kasparinskis, R.; Fridmanis, D.; Muter, O. (2020d) Bacterial and archaeal community structure in benthic sediments from glacial lakes at the Múlajökull Glacier, central Iceland. Polar Biology, 43, 12, 2085-2099.

Lamsters, K. (2021) Mūsdienu ledāji. Rīga : LU Akadēmiskais apgāds.

Shepherd, A.; Ivins, E.; Rignot, E.; Smith, B.; Van Den Broeke, M.; Velicogna, I.; Whitehouse, P.; Briggs, K.; Joughin, I.; Krinner, G.; Nowicki, S. (2018) Mass balance of the Antarctic Ice Sheet from 1992 to 2017. Nature, 558, 219-222.

Stivrins, N.; Lamsters, K.; Karušs, J.; Krievāns, M.; Rečs, A. (2018) Spheroidal carbonaceous particles in cryoconite sediment on the Russell glacier, Southwest Greenland. Baltica, 31, 2, 115-124.

The IMBIE Team (2020) Mass balance of the Greenland Ice Sheet from 1992 to 2018. Nature, 579, 233-239.

WGMS (2020, updated, and earlier reports). Global Glacier Change Bulletin No. 3 (2016-2017). Zemp, M.; Gärtner-Roer, I.; Nussbaumer, S. U.; Bannwart, J.; Rastner, P.; Paul, F.; Hoelzle, M. (eds.) ISC(WDS)/ IUGG(IACS)/UNEP/UNESCO/WMO. Zurich : World Glacier Monitoring Service. 